\title{
Litteratur.
}

Manuel historique de la question du Slesvig. Pullié sous la direction de Franz de Jessen.

Copenhague. 1906.

Da de "Samvirkende Sonderjydske Foreninger" 1901 udsendte den af Franz v. Jessen redigerede "Haandbog i det nordslesvigske Spørgsmaals Historie", bebudedes det, at der senere vilde udkomme en noget forfransk udgave. Denne har nu efter adskillig ventetid kortet set dagens lys og fortjener nok et par ord til velkomst, så meget mere som den ingenlunde er en blot og bar oversættelse af „Haandbogen“. Dette ligger i sagens natur. Thi medens den danske udgave selvfolgelig $i$ forste række er beregnet p£ danske læsere, henvender den franske manuel sig til udlandet. Med rette har udgiveren $i$ en lille selvstændig redegørelse for varkets tilbliven og formål gjort opmærksom på det uheldige i, at Evropas opfattelse af nationalitetskampen i Sonderjylland sågodtsom udelukkende hviler p\& oplysninger fra tysk side. Dansk er jo nu engang ikke noget verdenssprog, og ret forståelig er det da de tyske pressebureauers telegrammer og de ledende tyske avisers 
artikler, der danner grundlaget for udlandets rent faktiske viden. Selv om derfor de tyske handlinger og synspunkter vækker modsigelse hos andre nationer, vil et virkningsfuldt forsvar for danskhedens ret så at sige blive umuligt, da forsvareren intet materiale har til sin rådighed og praktisk set $\mathrm{i}$ de fleste tilfælde or ude af stand til at skaffe sig det. Lyriken kommer da som oftest $\mathbf{i}$ de for os gunstige indlæg til at erstatte realiteterne, til syvende og sidst dog det der bider bedst på den offentlige mening. For at tage et enkelt exen:pel vil enhver uhildet fremmed med lethed kunne finde på en hel hohen stærke adjektiver til karakteristik af de projsiske myndigheders adfærd overfor optanterne, men om han af sig selv vil kunne finde det mest bidende tillægsord, ordet „ulovlig“, er vist tvivlsomt. $\mathrm{Og}$,ulovlig“ er nu engang intet rart adjektiv at få hæftet på sig tilmed for en så udpræget retsstat som Prøjsen.

Ved den franske udgave af "Haandbogen“, der p̊ dansk alt har stået sin prøve, er der nu rådet bod på denne mangel. Udlandets presse og dets ledende mænd har ved den fået midler $\mathrm{i}$ hænde til at skabe sig en på saglige grunde støttet opfattelse af det nordslesvigske spørgsmål såvel i dets helhed som i dets talrige enkeltheder. Ligesålidt som sin furgænger indeholder denne håndbog nogen polemik mod tyske anskuelser eller nogen kritik af den projsiske regerings foranstaltninger. Den er ikke skreven som et indlæg i de øjeblikkelig brændende spørgsmål, tager ikke sigte på dagen i dag, men giver sine læsere de rent faktiske 
oplysninger, der er nødvendige til at forstå, hvad der er sket, såvelsom hvad der vil ske.

Men adskilligt af det stof, danske nødig vilde undvære $\mathrm{i}$ en virkelig håndbog $\mathrm{i}$ det nordslesvigske spørgsmål f. ex. det biografiske lexikon og den detaillerede valgstatistik, har selvfolgelig ingen storre betydning for udenlandske benyttere; dem interesserer stemmeantallet i Felsted sogn ligesålidt som H. P. Hanssens fødested! Ret naturlig er derfor den danske udgave af båndbogen på flere punkter bleven stærkt omredigeret. Ligefrem oversatte er kun enkelte af de mere historiske afsnit som professor Wimmers afhandling om runemindesmærkerne, professor Steenstrups om stednavnene, bibliothekar Flberlings om delingstanken og skoleinspektør P. Lauridsens om ældre sprogforhold. Andre som oversigten over de vigtigste sonderjydske statsakter og den fyldige befolknings- og erhvervsstatistik er omarbejdede og stærkt sammentrængte. Den af P. K. Thorsen givne skildring af "sprog og nationalitet" fremtræder $\mathbf{i}$ en næsten fuldstændig omskrevet skikkelse, og endelig er der kommen en række helt nye afsnit til. Elberling har således gjort rede for de begivenheder, der forte til tabet af Sonderjylland, hvis politiske historie siden 1864 er fortalt af P. Simonsen. Nicolai Svendsen har skrevet om skolens og kirkens gradvise fortyskning, Nikolaj Andersen om forsvaret for det danske sprog gennem sprog- og skoleforeningen og om pressen. Det sidste afsnit er ledsaget af en kurios statistik over de frihedsstraffe, der $\mathrm{i}$ tidens løb er idømt den nordslesvigske presses mænd; alt $i$ alt bliver det $182^{2 / 3}$ manned, af 
hvilke ikke mindre end $50^{1 / 8}$ falder på afdøde redaktor Jessen.

Først og fremmest må af det ny tilkomne nærnes professor Matzens indgående og omfangsrige afhandling om optantsagen, der fylder så nær en fjerdedel af hele bogen, samt $H$. V. Clausens oversigt over sprogforholdene i Nordslesvig siden 1864 med det dertil hørende sprogkort. Et udsnit af dette, omfattende Åhenrå og Sønderborg amter, var alt kommen frem i "Haandbogen“, men nu er kortet fuldført for hele Nord- og Mellemslesvig, således at der pa grundlag af indhentede oplysninger fra stedkendte Mænd er gjort rede for antallet af dansktalende, tvesprogede og tysktalende husstande i hver enkelt nordslesvigsk kommune, medens forfatteren for Mellemslesvigs vedkommende har indskrænket sig til at give procenttallet af de dansktalende. Målet har været at skaffe oplysninger om sprogforholdene $\mathbf{i}$ familjen hos alle bosatte grundejende mænd, idet besiddelsen af jord med rette er anset for at være. det egentlig bestemmende med hensyn til landets nationalitet. Det har da rist sig, at af den fast bosiddende befolkning i Nordslesvig havde $95 \%$ dansk og 3,6\% tysk til hussprog, medens $1,4 \%$ benyttede begge sprog. Uafhængig af den officielle statistik og kontrollerende denne - hvad der højlig kan gøres nødig - er der herved skabt en pålidelig oversigt over Nordslesvigs sprogforhold, der til alle tider vil stå som mønstergyldig.

Men sprogkortet giver ikke blot statistisk materiale, det fastslår tillige en kendsgerning, som vi har godt af årle og silde at blive mindede om, selvom 
den for mange har en lidt ubehagelig klang. $O g$ det er, at vil Nordslesvigerne hævde deres nationalitet, er det ikke nok, at de bevarer deres sprog. Thi det høje procenttal dansktalende selv $\mathrm{i}$ de sydligste kommuner i Mellemslesvig - f. ex. Hjoldelund 86, Sillerup 87, Østenå 80 - sammenlignet med stemmetallene og de nationale foreningers medlemslister viser tilfulde, at sproget alene gor det ikke. Nej skal nationaliteten bevares, må også forbindelsen med den danske kultur stadig holdes redlige. Hver sang der synges, hver avis der læses, hvert foredrag der høres, hvert forsamlingshus der bygges, er et bånd, der binder de danske Nordslesvigere til den kultur, de nu engang naturnødvendig tilhører. Og opgiver de den, hvad får de så i stedet? Ikke den tyske! Hertil vil der behoves generationer, thi man skifter nu engang ikke kultur og folkekarakter med samme lethed, som man tager en ny trøje på. Nej befolkningen vil drive ind i en materialismens dodvande, hvor man trækker nathuen ned over øjnene og stopper sine orer for alt, hvad der går ud over det rene madstræb - det være sig nu dansk eller tysk - hvor ringridning, „æggeløb, sækkeløb og kringlebidning“ sammen med „Kriegervereins"møder vil være folkets sondagskost og eneste afvexling fra hverdagslivets rugbrød. Der er heldigvis ingen fare for, at det $i$ lange tider skal komme såvidt, men de mange der tror, at de opfylder deres nationale borgerpligter, når de blot taler dansk, kan dog have godt af engang imellem at tænke på de $86 \%$ i Hjoldelund.

H. V. Clausen har også bistået ved tegningen af det smukke kort over hele hertugdømmet, der ledsager 
værket, ligesom han $\mathrm{i}$ dettes slutningskapitel har givet en skildring af folket og landet, $i$ hvilken de stemningsfulde landskabsbilleder selv $\mathbf{i}$ det fremmede klædebon har bevaret deres ejendommelige skønhed.

I en anmeldelse af "Haandbogen", der $i$ sin tid fremkom her i tidsskriftet, udtaltes det, at forst tiden vilde vise, hvorvidt værket havde nået det mål, udgiveren havde haft for øje. Dette gælder selvfolgelig i om mulig endnu højere grad for den franske udgave, men man må dog have lov til at tage varsel af den almindelige udbredelse og anerkendelse, „Haandbogen“ alt har vundet, såmeget mere som der er foretaget flere ret heldige ændringer $i$ værkets plan. Det er således absolut en forbedring, at der nu findes et afsnit om pressen og de nationale foreninger, mellem hvilke man dog savner Vælgerforeningen. Ligesom den tyske forening må den opsøges i redaktor P. Simonsens grundige og velskrevne oversigt over landets politiske historie. Derimod synes redaktoren vedblivende at lide af en ulykkelig kærlighed til de stakkels selvmordere, der fär en pæn behandling med to decimaler, medens man stadig savner et par tal til oplysning om jordens fordeling og ejendommenes størrelse.

Til slut må det siges, at den franske udgave ligesom sin forgænger fremtræder $\mathrm{i}$ en skikkelse, der er til al ære for dansk boghåndværk - stadig dog med undtagelse af indholdsfortegnelsen!

M. Mackeprang. 


\section{Dağshistorie 1905.}

Tildragelser vedrorende Nordslesvig optegnede efter

Tidsfølgen.

1. Januar. Pastor v. Brincken holder sin Afskedsprædiken i Spandet Kirke. (Jfr. 30. September 1904.)

2. Jumuor. Kathrine Johansen Fink, født Hansen, i Bøffelkobbel, der siden 1864 sammen med sin Mand har fredet om "Graven ved alfar Vej", dør.

4. Jamuar. Bisidderretten i Toftlund idømmer Skomager Christian Lastein i Birkelev en Bøde paa 30 Mark, fordi han har holdt sin Datter, der var fyldt 14 Aar i September og ikke skal konfirmeres i Statskirken, hjemme fra Skolen siden 1. November 1904.

5. Jamuar. Pastor N. H. Jorgensen i Kolding, fra 1852 til 1867 Præst i Vodder, dor

12. Junuar. Anden Direktør ved Skærbek Kreditbank, H. Paack, forsvinder med 8000 Mark af Bankens Penge.

13. Jumurr. Kigsdagsmand Jessen omtaler i den tyske Rigsdag nordslesvigske Tilstande paa Retsplejens Ounraade, især Optantsagerne og nogle Pressesager. 14. Januar. I den tyske Rigsdag holder Konsistorialpræsident Dr. Stockmann en længere Angrebstale mod Rigsdagsmand Jessen. Denne tager straks til Genmæle og fremhæver blandt andet, at ikke engang Dr. Stockmann som "den tyske Forening"s Talsmand vilde forsvare den statsunderstottede Presse i Nordslesvigr

Gaardejer Laust Arnum i Bovlund, der den 4. Januar fyldte 70 Aar, faar overrakt en Livrente som Hædersgave til Paaskønnelse af hans Arbejde i Landbrugets Tjeneste.

15. Jınuar. "Nordslesvigsk Børneblad" udkommer ikke mere selvstændigt, men følger fra nu af under Titlen 
"Børneblad" med samtlige danske Blade i Nordslesvig.

17. Januar. Overlærer Johannes Kaper i Kobenhavn, fra 1863-64 Adjunkt i Flensborg, dør (født i Lindholm).

24. Januar. "Sonderburger Zeitung“ meddeler, at den 18aarige Tjenestekarl Jørgen Iversen fra Sønderby paa Kajnæs er bleven udvist, fordi han i et Skænderi ved en Danseforlystelse har kaldt en indvandret tysk Tjenestekarl „en tysk Hund“. Den udviste er i Forvejen bleven idømt en Bøde paa 20 Mark for sine Ytringer.

28. Januar. Lensgreve Hans Schack til Schackenborg, Kredsdagrsmand, Synodemedlem, Patron for fire Kirker, Formand for den nordslesvigske Asylforening $\mathrm{m} \mathrm{m}$, dor 52 Aar gammel. I Fællessynoden har han flere Gange taget Ordet for to Timers Undervisning i dansk.

9. Februar. Aftæg-tsmand Jørgen Nissen i Hajstrup, en god dansk Mand, dør 97 Aar gammel (født 7 . Juni 1808).

13. Februar. I den prøjsiske Landdag omtaler Landdaysmand $H$ P. Hanssen Optantspergsmaalet or de lovstridige Udvisninger i Nordslesvig. Han minder om, at silen 1902 er over 1200 fodte Slesviyere blevne gjorte til Optanter, deriblandt Veteraner fra Krigen 1870 og flere Hundrede yngre Mrend, som har aftjent deres Værnepligt $i$ den projsiske Hær. Den derved hidførte Forvirring $i$ alle $\mathrm{Op}$ tionen vedrørende Spørgsmaal er uden Lige. Ret staar imod Ret, Domstol imod Domstol, den nuværende Forvaltning imod den tilligere o. s. v. Taleren opfordrer Regeringen til at ordne Spurgsmaalet ved en international Overenskomst med Danmark. - Indenrigsminister Hammerstein beklager de nuværende Forhold, men mener, at hvis den danske Agitation ikke var saa stærk, vilde Regeringen vise sig mere imødekommende og naturalisere $i$ stort Omfang.

16. Februar. I den prøjsiske Landdag retter Landdagsmand Julius Nielsen en skarp Kritik imod Forvaltningen i Nordslesvig. Han paataler især Ombytningen af Tjenestefolk som staaende $i$ absolut Modstrid med Regeringens Forsøg paa at hindre Landarbejderes Kontraktbrud ved Lov og kritiserer dernæst de økonomiske Forhold i Haderslev Amt - Landdagsmand Bachmann fra Haderslev betegner Nielsens Klager som ugrundede, og Indenrigsminister 
Hammerstein erklærer, at hans Embedsmænd handlede efter Ret og Samvittighed og i Overensstemmelse med Centralforvaltningen

20. Februar. Paa et Møde i Tinglev vedtager en Del Tyskere at oprette en tysk Folkehøjskole for unge Piger. Skolen skal ligge i Tinglev.

2. Marts. Rigsretten i Leipzig stadfæster Flensborg Landsrets Dom mod tidligere Pastor Jacobsen (2 Maaneders Fængsel og 900 Mark i Bøde) og Bogr bolderne M. E. Rabe og Kr. Petersen (hver 1 Maaneds Fængsel og 600 Mark i Bøde) for strafbart Forhold vedrørende Kunstvæveskolen i Skærbæk (Jfr. 27. Juni 1904).

3. Murts. Landsretten i Flensborg idømmer Journalist M. Dall ved "Hejmdal" en Bøde paa 200 Mark for at have fornærmet Amtsforstander Klinker i Nordborg ved en Meddelelse i det nævnte Blad, der gik ud paa, at Amtsforstanderen under en Gudstjeneste havde anbefalet en Tjenestepige, som var bleven bortvist fra en dansk Gaardmand, til en Tysker.

6. Marts. Pastor A. P. M. Leth i Middelfart, fra 1850 til 1863 Præst i Aabenraa, dør 83 Aar gammel (født 1822 i Nyborg).

10. Marts. Landsretten i Flenshorg stadfæster Haderslev Bisidderrets Dom af 8 . September 1904, hrorved tidligere Landmand og Mælkehandler i Aabenraa, Søren Knudsen Midtgaard var bleven idømt 1 Dags Arrest for ulovlig Till agevenden.

13. Murts. Landsretten i Flensborg stadfæster et Straffemandat paa 10 Mark, som Journalist E. Christiansen ved "Flensborg Avis" var ikendt som ansvarhavende for en unøjantig Meddelelse om en Difteritisepidemi.

15. Marts. I den tyske Rigsdag taler Rigsdagsmand Jessen om Optantsagen og gør særlig opmærksom paa Modsætningen mellem. dette Spørgsmaals Behandling i Elsas og Slesvig. Statssekretær Posadowski beinærker dertil bl. a, at de Folk, der udvistes fra Slesvig, havde agiteret mod Prøjsen.

16. Marts. Bisidderretten i Haderslev frikender Redaktoren af "Schleswigsche Grenzpost", K. Strackerjan, for Fornærmelse mod Redaktør Jessen i Flensborg i noyle Tilfojelser til en af denne indsendt Berigtigelse.

17. Marts. I den tyske Rigsdag hævder Rigsdagsmand Jessen over for Statssekretær Posadowskis Ud- 
talelser to Dage forinden, at Retten til Udvisning ikke gælder over for Optanter med Indfødsret, og at hele den nordiske Retsvidenskab har betegnet den prøjsiske Fremfærd som Retsbrud og Traktatbrud.

28. Marts. Forhenværende Teglværksejer M. Hollensen i Mølmark, Valgmand $\mathrm{m} \mathrm{m}$, dør 87 Aar gammel.

30. Marts. Købmand H. N. Paulsen i Aabenraa, Medstifter af "Den nordslesvig'se Folkebank" og tidligere Direktør for det derværende Aktiebryggeri, dør 76 Aar gammel.

27. April. Bisidderretten i Haderslev idømmer Maskinbygger Mink og Mekaniker Weppler hver en Bøde paa 10 Mark for ved en Maskerade at have sunget "I alle de Riger og Lande".

1. Maj. Den tidligere Udgiver af "Tonderner Nachrichten", Osvald Olesen, paabegynder i Haderslev Udgivelsen af et nyt tysk Blad, "Norlische Post", der bebudes at skulle kæmpe „for Frihed og Ret ${ }^{\mu}$.

6. Mraj. Den blaa Sangbog heslaglæegges hos danske Boghandlere i Sønderborg, Haderslev, Toftlund og Rødding.

11. Maj. Den blaa Sangbog beslaglægges paa Sprogforeningens Boglager paa "Folkehjem“ i Aabenraa og eftersages hos dervæerende Boghandlere.

Overlandsretten i Kiel forkaster den af Journalist E. Christiansen ved „Flensborg Avis“ mod Flensborg Landsrets Dom af 13. Marts nedlagte Revision.

12. Maj. Lrmagersvend $\mathrm{H}$. Kr. Jensen hos Urmager Suurballe i Haderslev udvises med 24 Timers Frist, fordi han $i$ sin Tid har sunget "I alle de Riger og Lande".

15. Maj. Paa et Møde i Haderslev oprettes en Hesteavlsforening for Haderslev og Omegn. Der indmelder sig 70 Medlemmer.

18. Maj. Bisidderretten i Hadersler idømmer Redaktøren af "Schleswigsche Grenzpost", K. Strackerjan, en Bøde paa 400 Mark, fordi han forst paa et aabent Brevkort og senere tillige $i$ to Artikler i sit Blad har sigtet Grosserer Julius Nielsen i Haderslev for at have brudt sin Ed som Landdagsmand.

Justitsraad Emil Ebsen i Flensborg, i over en Menneskealder en af de mest benyttede Sagførere i Flensborg og dansk Forsvarer $i$ mange politiske Retssager, dør 71 Aar gammel. 
25. Maj. Kammerretten i Berlin stadfæster Toftlund Bisidderrets Dom af 4. Januar, hvorved Skomager Kristian Lastein i Birkelev ikendtes en Bøde paa 300 Mark for Skoleforsømmelse. Stadfæstelsen begrundes med, at Skolepligten skal vedvare til det Tidspunkt, da Børn kan blive konfirmerede i Statskirken.

30. Maj. Den tyske Rigsdag erklærer enstemmigt den af to Kriminalbetjente den 17. Marts 1904 foretagne Husundersøgelse paa „Flensborg Avis"s Kontor for en Krænkelse af Artikel 31 i den tyske Rigsforfatning (om Rigsdagsmændenes Urørlighed). Ved denne Lejlighed paataler Rigsdagsmand Storz af det sydtyske Folkeparti Udvisningerne og andre Forholdsregler i Nordslesvig og mener, at sligt Tvangsstyre maa skade Prøjsens og Tysklands Stilling i Udlandets Omdømme. Paa Konsistorialpræsident Stockmanns Spørgsmaal om, hvor stort et Tilskud "Flensborg Avis“ vel fik, svarer Rigsdagsmand Jessen, at et Blad med et Oplag paa 8-9000 Eksemplarer ikke behøver nogen Lnderstøttelse udefra, og det fik hans Blad heller ikke.

5. Juni. Peter Skau paa Bukshave fylder 80 Aar.

20. Juni. "Den alsiske Landboforening", der i Februar har bestaaet i 50 Aar, holder Dyrskue i Ketting. Der er tilført rigelig 150 Dyr foruden Maskiner og Husflidsarbejder, og i Fællesspisningen deltager ca. 400 Personer.

21. Juni. Angelboen Journalist Th. Brix, der ofte har udtalt sig skarpt imod Tvangsstyret i Nordslesvig, dør.

28. Juni. Bisidderretten i Sønderborg frikender Boghandler Joh's. Moldt for at have overtraadt Politiforordningen af 28 Avgust 1866 ved at afsætte danske Viser af ophidsende Indhold (den blaa Sangbog) med den Begrundelse, at den nævnte Forordning ikke kan anvendes.

1. Juli. Smaabanen fra Haderslev til Skodborg aabnes for Færdselen.

2. Juli. Fru Marie Kasch, født Holtum, i Flensborg, kendt for $\sin \mathrm{Omhu} \bmod \mathrm{de}$ saarede danske Soldater $\mathrm{i}$ 1864, dør 82 Aar gammel.

5. Juli. Sønderborg Provstisynode vedtager med to Tredjedeles Flertal et af Gaardejer Nielsen i Mjang stillet Andragende til Fællessynoden om at sørge for, at der i de Skoler, hvor der gives dansk Religionsundervisning, indføres to danske Sprogtimer. Af 
Præsterne stemmer kun Hansen fra Dybbøl for Andragendet

16. og 17. Juli. Det fjerde danske Aarsmøde afholdes $\mathrm{i}$ Forsamlingshuset i Haderslev. (Jfr. Sj. Aarb. 1905, Side 303.)

24. Juli. Landsretten i Kiel idømmer den ansvarhavende ved "Schleswig - Holsteinische Vokszeitung “, D. Ivers, 3 Maaneders Fængsel for at have fornærmet Landraad Becherer i Haderslev og Amtsforstander Valentiner i Tyrstrup i en udforlig Omtale af Finnemann-Sagerne og Forsøget paa at gøre Gaardejer Timmermann i Skærbæk til Optant samt af de 2000-Mark-Affærer, der formentlig stod i Forbindelse dermed, og Konen Hansen fra Esbjærg, der i sin Tid vidnede mod Finnemann. - Ivers afsoner sin Straf fra 29 Avgust til 29. November.

27. Juli. Haderslev Provstisynode vedtager med 32 af 61 Stemmer følgende Tilføjelse til Beretningen om de kirkeligre og sædelige Tilstande: "I Tilslutning til Beretningen udtaler Synoden en Beklagelse af, at der ikke er blevet taget Hensyn til Synodens tidligere Beslutninger vedrørende Indførelse af tvungen dansk Sprogundervisning $i$ Skolen i mindst to Timer". Af Præsterne stemmer kun Fischer fra Fjelstrup for Tilføjelsen.

Tørninglen Provstisynode vedtager med 42 Stemmer et Andragende til Fællessynoden om at indvirke paa Regeringen i Retning af Indførelse af to danske Sprogtimer. Af Præsterne stemmer kun Zerlang fra Gram for Andragendet. - Efter Forslag af Timmermann fra Skærbæk vedtager Synoden desuden, at der skal tillades de Børm, der har faaet tysk Religionsundervisuing i Skolen, at modtage Kontirmationsforberedelsen paa Dansk.

8. Argust. Frimenighedspræst Rasmus Thomsen i Haderslev dør efter længere Tids Sygdom (født d. 3. Avgust 1849 i Anslet).

Husmand Jørgen J. Fink i Bøffelkobbel dør 88 Aar gammel. (Jfr. 2 Januar.)

6. September. Landsretten i Flensborg nedsatter den af Bisidderretten i Haderslev den 18. Maj Redaktør Strackerjan i Haderslev idømte Bøde for Fornærmelse mod Landdagsmand Julius Nielsen fra 4(10 Mark til 150 Mark, idet den udtaler, at Nielsen havde krænket sin Ed som prøjsisk Landdagsmand, og at den Anklagede ved at foreholde ham dette havde varetaget berettigede Interesser; 
i de to omhandlede Artikler var han imidlertid i Formen gaaet ud over Maalet for det tilladelige.

10. September. Frimenighederne holder deres fælles Aarsmøde i Skærbæk. Til Gudstjenesten or der mødt 500 Mænd og Kvinder, og om Eftermiddagen er der Møde med henved 600 Deltagere.

12. September. Provst L. Reuter i Broager dør 69 Aar gammel (født i København).

13. September. Bisidderretten i Aabenraa idemmer Tobaksfabrikant M. Andresen som Udgiver af den blaa Sangbog en Bøde paa 50 Mark for at have afsat danske Viser af ophidsende Indhold.

14. September. Bisidderretten i Haderslev idømmer Boghandlerne Karl F. Nielsen og P. Christensen dersteds en Bøde paa hver 10 Mark for at have solgt Eksemplarer af den blaa Sangbog, der af den nsagkyndige" Latinskolelærer Professor Nis Ankjer Schrøder betegnes som det farligste Agitationsmiddel, Danskerne ejer.

15. September. Forsamlingshuset i Hjerting indvies.

29. September. Landsretten i Flensborg idømmer Landdagsmand H. P. Hanssen i Aabenraa 3 Maaneders Fængsel og Litterat Nikolaj Andersen sammesteds en Bøde paa 300 Mark for Fornærmelse imod Landraad Becherer i Haderslev og Amtsforstander Valentiner $i$ Tyrstrup. Hanssen havde $i$ en Artikel "Køllerpolitikken “ i „Sønderjydske Aarbøger" 1904, som Andersen var ansvarbavende for, omtalt Optantlaveriet og da navnlig Side 286 det i Finnemanns Sag af Administrationen førte upaalidelige Vidne, Konen Bodil Hansen fra Esbjærg, og hendes Udsagn om Tilbuddet af en Belønning paa 2000 Mark. Under Forhandlingen afskærer Retten skarpt de anklagede fra at inddrage den hermed nær beslægtede Timmermann-Sag i Vidneføretsen og saaledes fra at afkræfte det fornærmelige $i$ de paaklagede Udtalelser.

10. Oktober. Optantspørgsmaalet bringes paa Tale i det danske Folketing. Drøftelsen fortsættes den 13., 14. og 17. Oktober.

15. Oktober. Thade.Petersen i Radding vælges til Frimenighedspræst i Haderslev $i$ afdøde $R$. Thomsens Sted. Han præstevies den 19. November.

16. Oktober. Rigisretten i Leipzig stadfæster Flenshorg Landsrets Dom af 3. Marts, hvorved Journalist M. Dall ved "Hejmdal" idømtes en Bøde paa 200 
Mark for Fornærmelse mod Amtsforstander Klinker i Nordborg.

18. Oktover. Bisidderretten i Toftlund idømmer Boghandler Niels Hansen dersteds en Bøde paa 10 Mark for Salg af den blaa Sangbog. Den "sagkyndige" Latinskolelører Professor Schrøder fra Haderslev betegner under Retsforhandlingen 16 Sange, deriblandt nogle Salmer og Gravsange, som „betænke-

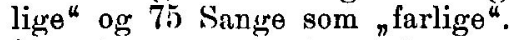

21. Ohtober. Paa et Møde i Flensborg oprettes et „Kirkeligt Samfund for Flensborg og Omegn" med det Formaal at støtte Afholdelser af danske Gudstjenester og kirkelige Møder i Flensborg.

22. Oltober. I Rødding Højskolegaards Have afsløres on Mindestøtte for Kornelius Appel, den første Frimenighedspræst i Nordslesvig.

1. Norember. Bisidderretten i Toftlund idømmer to Medlemmer af Bestyrelsen for det nye Forsamlingshus i Brøns, Møller L. Jacolssen i Brøns og Gaardejer T. Beier i Vangsbo, hver 50 Mark og Snedkersvend M. K. Bundesen i Raahede 10 Mark i Bøde for groft Uvæsen, begaaet af de to førstnævnte ved at have taalt, at der paa den nye Forsamlingsbygning var hejst Kranse med ikke blot gule, grønne og blaa, men ogsaa røde og hvide Baand, af den sidstnævinte ved at have bragt en saadan Krans derop.

5. November. Pastor F. R. C. Bülow, en Søn af Sejerherren ved Fredericia, indtil 1864 Præst i Dybhøl, dør 84 Aar gammel.

11. November. Den Retssag, som i 1902 var anlagt af Redaktør Jessen mod Fru v. Wildenradt-Krabbe, fordi hun havde betegnet det som Logn, at hendes Blad støttedes af den prøjsiske Regering, og mod 4 tyske Blade, som havde aftrykt den paagældende Artikel, er ansat til Forhandling ved Landsretten i Flensborg, men udsættes atter paa ubestemt Tid.

Bisidderretten i Flensborg idømmer Redaktøren af ${ }_{n}$ Schleswigsche Grenzpost ${ }^{4}$, K. Strackerjan, en Bøde paa 125 Mark for gentagne Fornærmelser mod Redaktor Jessen i Flensborg. Straffen kan sættes saa lavt, fordi Retten tilkender den Anklagede som "Forkæmper for Tyskheden" Værn af Bestemmelsen om berettigede Interesser.

3. December. Paa „Den tyske Forening for det nordlige Slesvig"s Aarsmøde i Klovtoft oplyses, at Foreningen har 5331 Medlemmer. 
12. December. Den tyske Folkehøjskole for unge Piger, der er bleven indrettet i Tinglev, indvies. Der er skaffet 16 Elever til Veje.

13. December. Pastor L. J. Levinsen i Hellerup, indtil 1864 Præst i Munkbrarup og Kværn i Angel, dør 84 Aar gammel.

15. December. Forsamlingshuset i Rurup indvies.

17. December. Forsamlingshuset i Brøns indvies.

18. December. Landsretten i Flensborg forkaster fire Indankninger vedrerende de af Bisidderretterne i Aabenraa, Haderslev og Toftlund henholdsvis den 13. September mod Tobaksfabrikant M. Andresen i Aabenraa, den 14. September mod Boghandlerne K. F. Nielsen og P. Christensen i Haderslev og den 18. Oktober mod Boghandler N. Hansen i Toftlund paadømte Sager for Udbredelse af den blaa Sangbog. Baade Statsadvokaten og Retten henholder sig til tidligere Kammerretskendelser, hvorefter Forordningen af 28. Avgust $1866 \mathrm{ikke}$ skal anses som ophrevet ved Presseloven af 1874. Landsretten i Flensborg frikender Moller L. Jacobsen fra Brøns for at have ovet groft Uvæsen ved Kransehejsningen paa Brøns Forsamlingshus. (Jfr. Toftlund Bisidderrets Dom af 1. November). T. Beier har taget sin Indankning tilbage, og $\mathbf{M}$. K. Bundesen er ikke modt til Forhandlingen. Frifindelsen begrundes med, at "det mægtige tyske Riges Undersattere" ikke kan føle sig truede ved net lille taabeligt Partis barnagtige Demonstrationer". 



\section{Jens Jessen.}

Den 22. Juli døde Rigsdagsmand Redaktør J. Jessen. Det havde været Hensigten, at „Sønderjydske Aarboger" allerede $\mathrm{i}$ dette Halvbind skulde have bragt en Levnedsskildring af den afdøde, hvis Virksombed har haft saa stor Betydning for Nordslesvig.

Dette har inidlertid ikke kunnet naas, hvorimod næste Halvbind vil bringe en Skildring af Jessen af Dr. phil. H. L. Moller.

Udgiverne. 




\section{"Sønderjydske Aarbøger" ulgrivne af}

\section{*. P. F̧anssen-Norremolle, P. Skau og Nikolaj findersen}

beryndte at udkomme 1889 og har siden $i$ en Rakke forskellige Bidrag skildret Slesvigs Historie, Land, Folk og Minder og har i politiske og statistiske Oversigter belyst Nordslesvigermes Kamp for Berarelsen af dansk Sproge ou Kultur.

„Sonderjydske Aarboger66 vil som hidtil behandle allo nordslesvigske sporgsmaal i videste Omfance, Historie og Politik, Sprog og Folkeminder, Naturforhold og Landolionomi. De vil desuden bringo Skildringer af andre Nationalitetskampei Fortid og Nutid og Droftelse af saadanne Forlold, dor direkte ellor indirekte staar i Forbindelse dermed.

,Sonderjydske Aarboger" udkommer to (i ange aarlint i Hefter paa tilsammen ontr. 20 Ark. Subskription modtages i alle. Boglader i Slesvig, Danmark, Norge og Sverige og i (iyldendalske Boghandel, Hovedkommissionen for de tre nordisko Lande. Prisen er 4 Kroner Aargangen; for Medlemmer af danske Foreninger i Nordslesvig 3 Mark.

\section{Indhold af 2. Halvbind 1906.}

Johunnes Lind hw k: Oversigt over historisk Litteratur fra Aarene 19(1-19):3 vedrarende Sonderjylland . . . . . . Side 177-213

H. P. H anssen-Norremolle: Det nordsles-

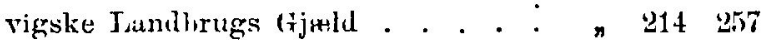

Ang. Jorgensen: Nugle Meddolelser om min

Lmbedsvirksomlud i Stalen Slesvig

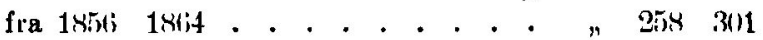

Thade Petersen: Det danske Aarsmode 1904i "302

Litteratur: Manuel historique de la question du

Slesvig unmellt af M. Mackeprang, 309314 Dagshicturie $1 ! k 5 \%$. . . . . . . . . . 